The Journal of the Oceanographical Society of Japan

Vol. 18, No. 1, March 1962

\title{
塩素量測定法の分析化学的研究
}

\author{
II 塩素量測定法の滴定の補正值 $\kappa$ の図式計算法*
}

輿水 直 文**

\section{The Study of Chlorinity Determinations}

\author{
II. The Graphical Method of finding the Correction " $\kappa$ " \\ in Chlorinity Determinations of Knudsen's Method
}

\author{
Naobumi KosHimizU
}

\begin{abstract}
The values of the correction " $k$ " in chlorinity determinations in Knudsen's Hydrographical Tables are generally mixed number. Then, the calculation of the interpolation of the actual titration value for finding the correction " $k$ " is troublesome, and, according to the author's calculation, the error of the correction " $k$ " is $0.01(\%)$ owing to the titration error and the drop error. The author has taken those errors of chemical analysis into account in the calculation of the value of $\kappa$, and calculated the values of the correction " $\kappa$ " by introducing directly the titration values of a which are integer. Using those values of the correction " $\kappa$ ", the author has deviced a graphical method finding the values of $\kappa$ when both $\boldsymbol{\alpha}$ and a are given.
\end{abstract}

\section{1. 結 論}

M. Knudsen ${ }^{1)}$ の Hydrographical Tables におい て述べている塩素量の測定の補正值 $\kappa$ の算出法は, 既知の塩素量の值 $\mathrm{Cl}$ と滴定補正值 $\kappa$ との関係より 滴定の読取值となるべき值 $a$ を逆算しいるために, 補正表に扔いて $a$ は一般に帯小数の值を示してい る。このために海洋観測において多数の試水の塩素 量を測定する場合に実際の滴定の読取值 $a$ について 補正值 $\kappa$ を求める場合の内挿法による計算が煩雑で ある。

著者は滴定の補正値 $\kappa$ の算出法として滴定の読取 值 $a$ を直接導入して算出式を求め, これに滴定誤差 及び滴誤差の分析誤差を補正して, 滴定の読取值 $a$ が $0 \leqq a \leqq 22$ の範囲において滴定補正值 $\kappa$ の值を計 算した。著者の算出法は $a$ にす心゙て整数值を与えて いるので, 実際の測定值 $a$ は一般に帯小数值であっ て,これに対する補正值 $\kappa$ を内挿法で求める場合に 容易であると同時に $0.01 \%$ の精度をもつ值が得られ る。これを更に図式計算法にすると一般海洋観測の 塩素量の測定の場合に一つのグラフで簡単に滴定の

* 1961年10月10日受理

** 舞鶴海洋気象台 Maizuru Marine Observatory
補正值 $\kappa$ が求められる。

\section{2. 補正値 $\kappa$ の図式計算法}

滴定補正值 $\kappa$ について著者が我々の標準温度 $15^{\circ}$ $\mathrm{C}$ に扔いて，滴定誤差及び滴誤差の分析誤差を算入 した $\kappa$ の補正数值表を用いて, 硝酸銀溶液の濃度を 標準海水で標定した時に得られる $\alpha$ に対して試水の 滴定の読取值 $\boldsymbol{a}$ が与えられた場合に, $a$ の補正值 $\kappa$ を求める図式計算法を行った。すなわち我々の塩素 量の測定の経験では, 海水ビュレット, 及び海水ピ ペットの両者の器差による組合せ器差に対する補正 值を正確に滴定した場合には，調製硝酸銀溶液の濃 度を標淮海水で標定したときの $\alpha$ の值は一般に

$$
-0.10 \leqq \alpha \leqq+0.10
$$

の範囲内にある。 $\alpha$ の值を上記の範囲にとってこれ をX軸にとり，一般の海洋観測の塩素量の測定に必 要な $15{ }^{\circ} 00 \sim 22.00(\%)$ の範図の滴定の読取值 $a$ の 整数が与えられた場合に， $\alpha$ の值に対する測定の補 正值 $\kappa$ を $\mathrm{Y}$ 軸にとって，Knudsen 方式による塩素 量の測定の補正值 $\kappa$ の図式計算を行った。

前報文において著者の算出した補正値 $\kappa$ の算出式

$$
\kappa=\kappa^{\prime}\left\{1-\frac{a \cdot \mathrm{N} \cdot \rho^{\prime}{ }_{15} \times 1.39 \times 10^{-3}}{(\mathrm{~N}-\alpha) \cdot \rho^{2}{ }_{15 . a}}\right\}
$$




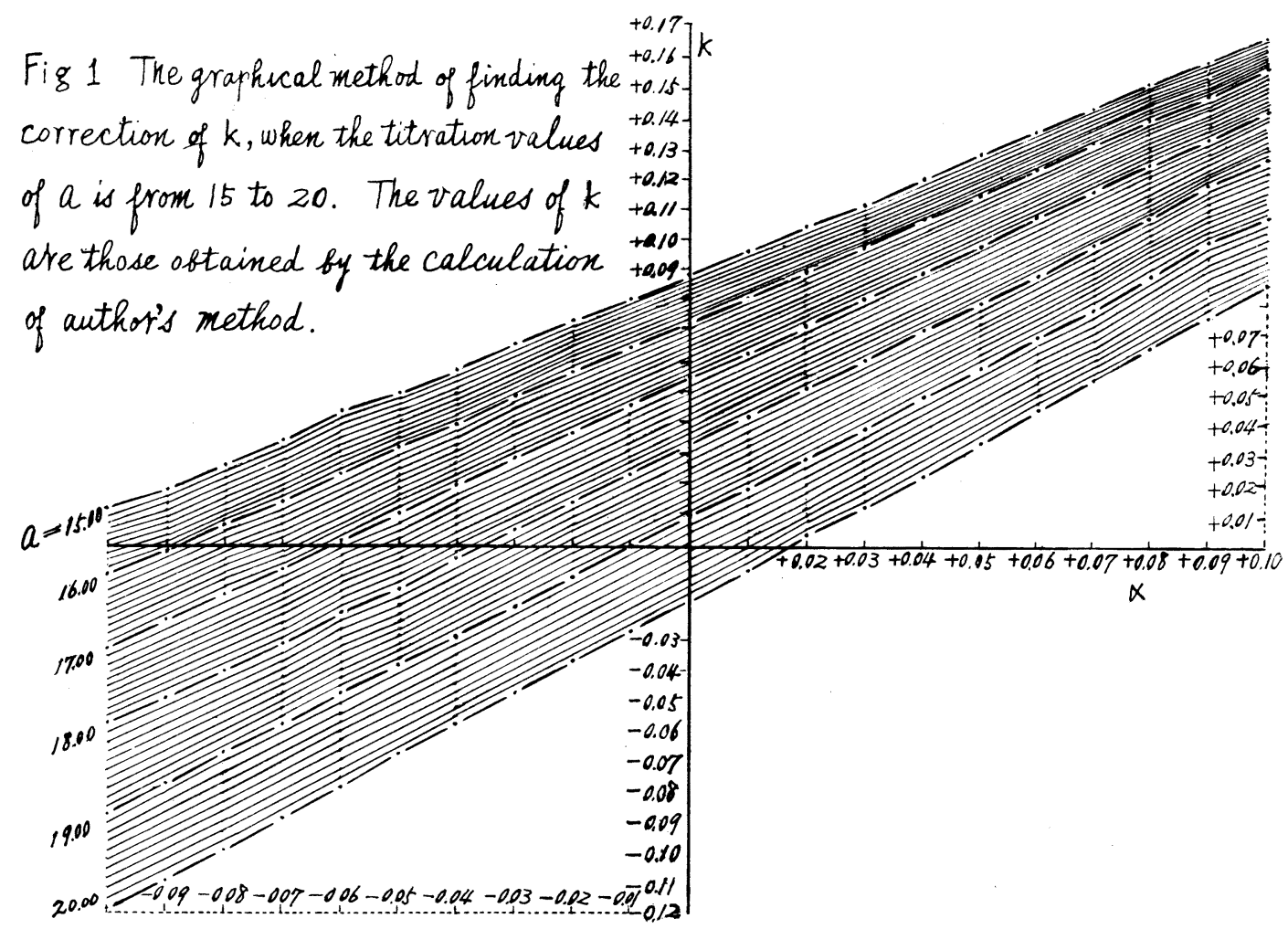

$$
\begin{aligned}
& +\mathrm{E} \cdot \operatorname{Acl} \frac{15+2(\mathrm{~N}-\alpha)}{15 \cdot \rho^{\prime}{ }_{15}} \cdot \frac{a}{\mathrm{~N}}-\frac{15+2 a}{15 \cdot \rho_{15} \cdot a} \\
& \quad+d\left(\begin{array}{c}
a-1) \\
\mathrm{N}-1)
\end{array}\right. \\
& \text { ここに } \kappa^{\prime}=a \frac{\mathrm{N} \cdot \rho^{\prime}{ }_{15}}{(\mathrm{~N}-\alpha) \cdot \rho_{15} \cdot a}-1
\end{aligned}
$$

$a:$ 試水の滴定の誤取值 $(\%)$,

$\mathrm{N}$ : 標準海水の塩素量 $(\% c)$

$\rho^{\prime}{ }_{15}: 15^{\circ} \mathrm{C}$ 標準海水の密度,

$\rho_{15}: 15^{\circ} \mathrm{C}$ の試水の密度

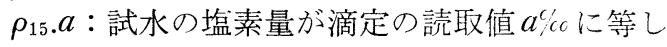

いとした場合の $15^{\circ} \mathrm{C}$ の密度,

$\alpha$ : 標準海水の塩素量 $\mathrm{N}$ と標準海水で硝酸銀溶 液滴定した值 $\mathrm{A}$ との差,

$\mathrm{E}:$ ：クム酸カリ指示薬の銀イオンに対する感 度,

$\mathrm{Acl}$ : 塩素の原子量,

$d:$ 滴定の終点過ぎた過剩量

上式において $a \leqq 22$ の場合

$$
\begin{gathered}
\text { 故に } \kappa \fallingdotseq a_{\left\{\frac{\mathrm{N} \cdot \rho^{\prime}{ }_{15}}{(\mathrm{~N}-\alpha) \cdot \rho_{15 . a}}-1\right\} \text { Ł寸れば }} \\
\frac{\Delta \kappa}{\Delta \alpha}=\frac{a \cdot \rho_{15}^{\prime}}{\mathrm{N} \cdot \rho_{15 . a}}
\end{gathered}
$$

故に滴定の読取值 $a$ の大きいもの程 $\frac{\Delta \kappa}{\Delta \alpha}$ の值が大 きくなって，図による内雨法は更に容易になる。 塩素量が小さく, すなわち $a$ の值が小さい場合は $\Delta \alpha$ の目盛りを適当に大きくすればよい。実際の 図式計算の場合 $\Delta \alpha$ を 0.01 とし，その目盛間隔を 5 糎の大きさに作図したものは使用に便利である。 Fig. 1.にぞの縮小したグラフを示す。

\section{3. 結 論}

M. Knudsen の Hydrographical Tables によ る塩素量の測定の滴定補正值 $\kappa$ の算出表は, 滴定 の読取值 $a$ として帯小数を与えているので, 実測 值 $a$ に対する補正值 $\kappa$ を内挿法で求める場合に煩 雑である。著者は直接滴定值 $a$ を導大寸る算出式 を得て， $a$ に整数值を与えて内㨂法による補正值 $\kappa の$ 計算を容易にしたが，更に一般の海洋観測に 便利のために一つのグラフによって補正值 $\kappa$ を求 める図式計算法を考案した。これによれば実際の 塩素量の測定の滴定補正値 $\kappa$ は $0.01 \%$ の正確度を もち, しかも多数の測定值の補正を迅速に行うこ とができる。

終りに御懇切なる御指導と御鞭達を賜わった京 都大学教授藤永太一郎博士, 京都大学名誉教授石 橋雅義博士, および気象研究所地球化学部長・東 京教育大学教授三宅泰雄博士に表心より感謝しま 
す。また御教示をいただいた舞鶴海洋気象台長川 瀬二郎氏，および塩素量の測定に関する質問に親 切な御返答をいただいた Dr. James W. McGary (Chesapeake Bay Institute, The Johns Hopkins University）に深謝します。

$$
\text { 文献 }
$$

1) Knudsen, Martin, Carl Forch, and S. P. L.
SORENSEN (1902):

Bericht über die chemische and phisikalishe Untersuchung des Seewassers und die Aufstellung der neuen Hydrographischen Tabellen., Wiss. Meeresuntersuch., N.F. Bd. 6, Kiel, 62pp. 2) J. W. McGARY (1954):

Chlorinity Determinations. Journ. Mar. Res. 13 (3), 245-253. 